\title{
Are the Hungarians on the Right Track Toward Sustainable Consumption?
}

\author{
Nóra Rodek \\ University of Pannonia, Hungary \\ Zsuzsanna Marton \\ University of Pannonia, Hungary \\ Ildikó Ernszt \\ University of Pannonia, Hungary \\ Zoltán Birkner \\ University of Pannonia, Hungary
}

\section{Abstract}

Business operation in Corporate Social Responsibility (CSR) approach supports competitiveness and sustainable development. In Hungary the approaches of social responsibility and sustainability started to develop after the change of regime, mainly through international corporate cooperation. However, in our days not only companies are expected to operate in a sustainable and responsible way, but it is indispensable that the demand and aspirations in this direction should be reflected in society as well, since besides processes applied in production, it is the consumption that can contribute most to the realization of sustainability. The purpose of this study is to examine whether consumers know the CSR activity of the shop they visit, as well as to highlight the aspects influencing their choice. Furthermore, the study also reveals the socially responsible activities that would be supported by them. The customers of an international food chain company - is a leader in CSR activities - were involved in the questionnaire survey.

Keywords: CSR, sustainable consumption, sustainable operation, conscious consumers

JEL classification: M14, M31

\section{Introduction}

Despite being a relatively new phenomenon, corporate social responsibility went through significant changes during its brief history. The process of globalization and the sharp increase in international trade have both drawn greater attention to it, however, the number of truly socially responsible companies hasn't shown a notable increase at the end of the 20th century (Haynes et al., 2016). Among the principles of sustainability, methods that are dedicated to environmental consciousness and protection of the ecosystem have only undergone a minimal amount of development. The increase in world trade implicitly brought on an increase in transportation, which, considering this mission (i.e. that of being environmentally conscious) represents unfavourable processes. Parallel to this, even though multinational companies' participation in CSR activities can be observed, household consumption is constantly on the rise and its structure shows no sign of major change (Subáné, 2005). Consequently, the responsibility of large corporations can be clearly demonstrated both in the shaping of consumer behaviour and in the exercisability of sustainable development. Responsible consumer behaviour is more and more 
evidently shaped by decision-making based on what the consumer thinks of a product, its lifecycle and the company that created it. Besides the well-known factors of product quality, price and brand, CSR communication is gaining ground too: its ability to introduce the truly responsible company that created the given product, together with showcasing the manufacturer's determination to not just improve its employees' quality of life or support local community goals, but also its environmental awareness in the processes of manufacturing and product distribution. Conscious customers value products that were made by environmentally conscious companies, however, they value those even more, who share more and better-quality information regarding their activities of the kind (Zoltayné, 2002). This study aims to examine how consciously Hungarian consumers choose new products and points of sales. We also examine whether they can be considered conscious customers, who know and pay attention to the store's CSR activity and what factors influence their choices: for instance, is it the store's CSR activity that attracts them to the given POS, or some other considerations such as comfort or accessibility? In our research we sought answers to the following questions:

RQ1: Do customers know the CSR activities of the store they are visiting?

$R Q 2$ : Does the store's CSR activity influence their decision making?

RQ3: What socially responsible activities would they support?

Customers of a multinational food chain company were involved in our questionnaire-based survey.

\section{Corporate Social Responsibility}

Sustainable development meets the needs of the present, without compromising the needs of the future generations (Brundtland, 1987). Although the conscious and environmentally decisions promoting sustainability refers to the future, they need to be taken into consideration in the present. CSR can be a great tool to achieve sustainable development.

According to World Business Council for Sustainable Development, the definition of CSR is the following: commitment of business to contribute to sustainable economic development, with the employees, their families, local community and society cooperating in order to improve the quality of life (European Commission, 2001). CSR is regarded as a set of tools that improves working conditions beyond legal requirements and it is favourable for the society (Vogel, 2006). Many companies are focusing on corporate social responsibility issues but unfortunately, most companies are still based on self-interest and make CSR the part of their economic calculation, which is the opposite of altruistic ethical behaviour (Holliday et al., 2002). The main points of Corporate Social Responsibility (CSR) concepts are; that after mapping who their stakeholders are, the company has to incorporate these CSR values and interests into their business operation while maintaining their profitability. Socially responsible behaviour radiates confidence towards both employees and consumers (Frank, 2004). Many companies, however, see that a few donations and environmental measures are enough for responsible behaviour. However, for the sustainable development a long-term strategy is needed. This is why Rodek (2018) defines CSR as follows: CSR is a way of thinking that, in cooperation with, and considering the interests of stakeholders of the given company, strives to decrease negative effects imposed on the environment and to better working conditions, while supporting social prosperity voluntarily beyond legal requirements, adjusted to its competencies and available resources. The idea of CSR must permeate the entirety of corporate operations, integrated into its core strategy. Another factor why corporate CSR is important is that it not only creates ownership value, but strengthens social values at 
the same time (Munilla \& Miles, 2005). According to Attila Chikán, results of CSR activity award increased competitiveness to companies pursuing them: "competitiveness and social responsibility, by the very nature of businesses, organically belong together" (Chikán, 2008, p. 12). This fact is further supported by an article published by Porter and Kramer in 2006 in the Harvard Business Review, in which they state that "strategic CSR means unambiguous competitive advantage for businesses" (Porter \& Kramer, 2006, p. 6). Such strategic decisions provide advantages for the company and society alike. According to a survey by Deloitte in Central Europe in 2015, 75\% of the corporate leaders who were asked believe that customers demand the choice to be able to choose from environmentally and socially conscious services and products. $45 \%$ of company leaders were of the opinion that responsible corporate leadership shall take a positive turn in the coming years, while $20 \%$ of them opined that such commitments shall reach strategic levels and become integral parts of business models. Development of CSR-based approach has come to the point where conscious utilization of its strategic capabilities and toolsets must be reckoned with. The strategy should also include the values, desires and aspirations of the stakeholders (Esse et al., 2012). The European Commission formulated its new CSR strategy on the 25th of October, 2011, creating a simplified definition that summarizes the essence of CSR approach: "the social effect of companies" activities is their responsibility" (European Commission, 2011).

\section{Responsible and sustainable consumption}

Creating a socially conscious consumers' environment is predominantly the task of the market actors. Businesses that are able to create their CSR activities in a way that incites responsible consumption have a greater ability to enhance and shape opinions. However, responsible consumption incitement isn't possible in the case of each and every market actor, since it can be hindered by external and internal factors alike. An example for such an internal factor might be a company's product structure, provided it doesn't promote sustainable consumption. An example for such an external factor could be distrust - consumers do not trust the company or reject its communication regarding sustainability (Kun, 2009; Kapusy, 2010).

There are two key roles in communicating social responsibility in corporate relationships: 1. it enables the organization to create a positive image of itself and communicate and introduce it in the same manner to its partners, 2. it enables partners to better know the company's clear and documented activities, opinion forming and - in case of relevant results - it affects consumer behaviour positively (Ransburg \& Vágási, 2011).

According to the research findings of Töröcsik (2011), dedication among consumers to environmentally conscious and sustainable behaviour is low, as social problems like poverty - create behavioural patterns that damage the environment, and as such, do not contribute to the realization of sustainable development. According to another Hungarian research, Hungarians expect a constant and genuine flow of information from companies, including that of their CSR activities. Those who were asked have considered quality CSR activity as a decisive factor when it comes to making purchase decisions. In the results of the research conducted by Noémi Nagypál Csigéné it is pointed out that younger generations are much more receptive to the idea of sustainable consumption than older people are, with the latter group's purchasing attitudes being more influenced by price sensitivity and product quality (Csigéné \& Görög, 2015). 


\section{Methodology}

We aimed to examine how conscious Hungarian consumers are when they choose products for purchase as well as the store where they make their purchases, to see if they can be categorized as conscious consumers who follow the CSR activities of the store they visit. We conducted our research in a local store of an international food store chain that is very active in CSR. We assumed that its customers know about the store's such efforts and that its CSR activity was one of the reasons they frequented the store. We conducted a questionnaire-based survey at LIDL in the spring of 2019, obtaining 652 samples. The questionnaire included 22 questions revealing general demographics and buying habits of the consumers together with the motivations for their shopping. The results were analysed via Microsoft's Excel spreadsheet and IBM's SPSS statistics analysis software.

\section{Results}

Table 1 indicates answers to the question why the questioned individuals shop at LIDL. Answer choices were somewhat guided, considering that they were to be marked on a 5-grade Likert scale to determine which factors describe the respondent best.

Table 1

The Aspects Influencing the Customers Choosing LIDL

\begin{tabular}{|c|c|c|c|c|c|}
\hline Examined aspect & $\begin{array}{l}\text { Not } \\
\text { typical at } \\
\text { all }\end{array}$ & $\begin{array}{l}\text { Somewhat } \\
\text { typical }\end{array}$ & $\begin{array}{l}\text { Can't } \\
\text { decide }\end{array}$ & $\begin{array}{l}\text { Mostly } \\
\text { typical }\end{array}$ & $\begin{array}{l}\text { Absolutely } \\
\text { typical }\end{array}$ \\
\hline Good value for money & $2,0 \%$ & $4,7 \%$ & $4,4 \%$ & $60,6 \%$ & $28,2 \%$ \\
\hline $\begin{array}{l}\text { Because of sympathy felt for } \\
\text { LIDL's social responsibility }\end{array}$ & $25,9 \%$ & $23,4 \%$ & $24,5 \%$ & $22,7 \%$ & $3,5 \%$ \\
\hline $\begin{array}{l}\text { Because of LIDL's own-brand } \\
\text { products }\end{array}$ & $8,0 \%$ & $23,7 \%$ & $7,4 \%$ & $42,7 \%$ & $18,2 \%$ \\
\hline The store is close to where I live & $12,7 \%$ & $25,9 \%$ & $3,2 \%$ & $35,5 \%$ & $22,7 \%$ \\
\hline $\begin{array}{l}\text { Because of fresh, quality } \\
\text { products }\end{array}$ & $3,1 \%$ & $8,1 \%$ & $6,6 \%$ & $56,7 \%$ & $25,6 \%$ \\
\hline $\begin{array}{l}\text { Other family members shop } \\
\text { here as well }\end{array}$ & $18,2 \%$ & $23,1 \%$ & $10,3 \%$ & $36,4 \%$ & $11,9 \%$ \\
\hline $\begin{array}{l}\text { Because of the availability of } \\
\text { Hungarian products }\end{array}$ & $14,7 \%$ & $26,0 \%$ & $13,5 \%$ & $36,9 \%$ & $8,9 \%$ \\
\hline $\begin{array}{l}\text { Because of fresh, healthy and } \\
\text { preservatives-free products }\end{array}$ & $9,3 \%$ & $19,8 \%$ & $17,2 \%$ & $43,0 \%$ & $10,7 \%$ \\
\hline $\begin{array}{l}\text { I like the textiles and clothing } \\
\text { items available at LIDL }\end{array}$ & $12,6 \%$ & $21,4 \%$ & $6,0 \%$ & $36,9 \%$ & $23,1 \%$ \\
\hline $\begin{array}{l}\text { I always find some non-food } \\
\text { product that is practical to me }\end{array}$ & $7,7 \%$ & $19,4 \%$ & $7,0 \%$ & $46,1 \%$ & $19,8 \%$ \\
\hline $\begin{array}{l}\text { Because LIDL supports } \\
\text { environment protection and } \\
\text { promotes various noble causes }\end{array}$ & $15,9 \%$ & $27,6 \%$ & $21,9 \%$ & $27,7 \%$ & $6,9 \%$ \\
\hline $\begin{array}{l}\text { Because of the kindness, } \\
\text { professionalism and helpfulness } \\
\text { of the employees }\end{array}$ & $17,3 \%$ & $26,0 \%$ & $14,2 \%$ & $31,7 \%$ & $10,7 \%$ \\
\hline $\begin{array}{l}\text { Because of items seen in their } \\
\text { print brochures }\end{array}$ & $8,0 \%$ & $15,5 \%$ & $5,4 \%$ & $48,2 \%$ & $23,0 \%$ \\
\hline $\begin{array}{l}\text { Because product selection is } \\
\text { easy to browse through and I } \\
\text { can be done with my shopping } \\
\text { quickly }\end{array}$ & $4,0 \%$ & $10,1 \%$ & $5,1 \%$ & $50,2 \%$ & $30,6 \%$ \\
\hline
\end{tabular}


In case of the aspects that are in connection with CSR, the ones that the majority responded are coloured. The aspects are marked with green that most typically influences the customers to choose LIDL. Light brown shows the aspect that less typically influences the respondents. Most of the customers $(60.6 \%)$ prefer to shop at the store because of its good value for money. Unfortunately, $25.9 \%$ of the respondents are absolutely indifferent regarding LIDL'S CSR activities and $24.5 \%$ of them can't decide whether such activities influence them or not when selecting a store to shop at. Only 23 people (3.5\% of all respondents) claimed that they shop at LIDL because they sympathize with the store chain's social responsibility activities $22.7 \%$ considered such activity more important than not, while $23.4 \%$ deemed it less important. Only $6.9 \%$ of the respondents choose LIDL for shopping because it supports environment protection and noble causes, whereas $27.7 \%$ of them see this as a rather - but not the sole most - important factor.

Table 2

To What Extent the Respondents Are Familiar with The Programs of LIDL Related To CSR

\begin{tabular}{cccccc}
\hline & & Frequency & Percent & Valid Percent & Cumulative Percent \\
\hline Valid & yes & 87 & 13,3 & 13,3 & 13,3 \\
& no & 565 & 86,7 & 86,7 & 100,0 \\
& Total & 652 & 100,0 & 100,0 & \\
\hline
\end{tabular}

Source: Authors' work

Based on the results shown in Table 1, those seen in Table 2 come as no surprise: $86.7 \%$ of the respondents (565 people) are unaware of LIDL's CSR activities. Only 13.3\% (87 people) claimed to have known and paid attention to the store chain's CSR. The fact that $32,8 \%$ of the respondents would be eager to know more about LIDL's CSR programmes, with $52.5 \%$ claiming to "maybe" being interested in knowing more about them can be considered a positive result. $14.1 \%$ of the people questioned opined that they are not interested in the store chain's CSR activities at all.

We also asked customers about their ideas regarding how the store chain's CSR programmes could be promoted more efficiently. $46.6 \%$ of them would like to see promotion programmes, such as family days, where each family member would feel engaged. $33.6 \%$ believe that cooking courses or health screenings would work best, while $17.7 \%$ opined that calls to various competitions would be most welcome, for instance, a drawing competition. 2.2\% of the respondent picked the "other" answer category, where they came up with the following ideas: product sample promotions, awareness-raising PR activities, leaflets/brochures, mobile applications, helping the needy with free food packages and less food thrown away. 
Figure 1

How the Information on the CSR Activities in LIDL Would Influence the Customers

It would have an impact on my decision if I knew more about the CSR activities of LIDL

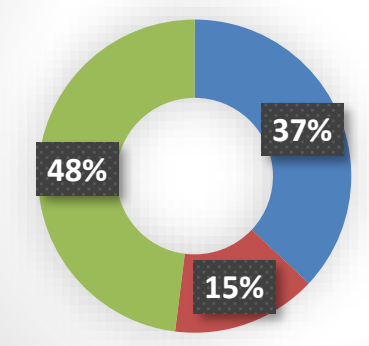

$\square$ YES

-NO

MAYBE

Source: Authors' illustration

$37 \%$ of the respondents would be influenced in choosing products to purchase if they had more information on CSR, 15\% wouldn't be influenced at all, while $48 \%$ "maybe" would. This result can be considered positive and is at the same time a message to the leadership of the local LIDL store that it would be well worth to communicate their CSR efforts to their customers. We also enquired if the respondents would participate in CSR activities: $30.7 \%$ of them claimed that they would participate in events or calls organized by LIDL, if they had more available information; $62.3 \%$ answered "maybe", while $7.1 \%$ would not take part in such programmes at all. Those, who opined would "maybe" take part in CSR activities are potential target groups for LIDL's campaigns - a large segment of customers who are worth addressing.

\section{Discussion}

Summarizing research results, it became apparent that 565 out of 652 respondents had no idea of LIDL's CSR activities (referring to "RQ1" being "Do customers know the CSR activities of the business they are visiting?").

RQ2: Does the store's CSR influence their decision making? Examining the answers given to the second question, it is obvious that most respondents mostly care about good value for money, quality fresh products and products without preservatives, LIDL's own-brand products, the available clothing items/textiles, non-food and the clear selection of products available, in this order. Environment protection and other noble causes have less effect on purchase decisions: results have shown that $21.9 \%$ of the respondents were unsure whether these aspects mattered to them, whilst $43.5 \%$ of them claimed that the store's such activities had no effect on their decision-making at all.

RQ3: what socially responsible activities would they support? Respondents would be glad to see the following CSR programmes occur:

- family days, where each and every family member would have something to engage in

- cooking courses

- health screenings

- calls and events (e.g. drawing competition)

- product promotion sampling (one that introduces environment protection aspects as well)

- awareness-raising PR activities (brochures, app) 
- helping people in need with food packages

- participation in a campaign that promotes prevention of wasting food.

\section{Conclusion}

The research is not considered representative, but in our opinion, it reflects the situation of Hungarian customers. The answer to the question- 'whether the Hungarians on the right track toward sustainable consumption'- is not easy because the results of the research show that they prefer to choose the store because of price and quality rather than its CSR activity. Based on this, I would say that they are not on the right track yet, but if we take into consideration that they are open to such activities, but not having enough information, then we can conclude that they can be on the right track if the stores and businesses will provide them information about their CSR activities, involve them in these programs and ask for their opinion. Unfortunately, in many cases, CSR programs are included only in the central strategy, but the member stores of the chain do not have their own programs at local level. It would be worth doing a further research on whether the members of the examined store chain adapt to the needs of the local community (they have their unique, local programs based on the local needs). In the introduction it was said that awareness raising, informing customers is the responsibility of the managers of the businesses, therefore they can do a lot to direct the Hungarian customers to the right track toward sustainable consumption.

\section{References}

1. Brundtland, H. (1987), "Report of the World Commission on Environment and Development: Our Common Future", Oslo, available at: http://www.un-documents.net/our-common-future.pdf (17 April 2019).

2. Chikán, A. (2008), "Vállalati versenyképesség és társadalmi felelősség" (Corporate competitiveness and social responsibility), Harvard Business Review Magyar Kiadás, pp. 6-13.

3. Csigéné, N. N., Görög, G. (2015), "A társadalmilag felelős fogyasztás egyes jellemzőinek vizsgálata egyetemi hallgatók körében" (Examining certain characteristics of socially responsible consumption among university students), Marketing és Menedzsment, Vol. 2, pp. 3-18.

4. Esse, B., Szántó, R., Wimmer, Á. (2012), "Business relationships and relationships with stakeholders - Perception of Hungarian executives", The IMP Journal, Vol. 6, No. 2, pp. 98-108.

5. European Commission (2001), "Green Paper: Promoting a European framework for Corporate Social Responsibility", Brussels, Commission of the European Communities.

6. European Commission (2011), "Corporate social responsibility (CSR)", available at: http://ec.europa.eu/enterprise/policies/sustainable-business/corporate-socialresponsibility/index en.htm (12 April 2019).

7. Frank, R. H. (2004), What Price the Moral High Ground? Ethical Dilemmas in Competitive Environments, Princeton University Press, Princeton.

8. Haynes, K., Murray, A., Dillard, J. (2016), Corporate social Responsibility: A Research Handbook, Routledge, New York, NY.

9. Holliday, C. O., Schmidheiny, S., Watts, P. (2002), Walking the Talk - The Business Case for Sustainable Development, Greenleaf Publishing, Berrett-Koehler Publishers, Inc, San Francisco, CA, USA.

10. Kapusy, P. (2010), Néhány gondolat a vállalatok fenntartható fejlődéséről. (In Eng.: Some ideas about the sustainable development of companies), Magyar Minőség, Vol. 44, No. 1, pp. 7-11.

11. Kun, A. (2009), A multinacionális vállalatok szociális felelőssége- CSR alapú önszabályzás, kontra (munka) jogi szabályozás (Social Responsibility of multinational companies- CSR-based self-regulation versus (work) legislation), Ad Librum, Budapest. 
12. Munilla, L. S., Miles, M. P. (2005), "The Corporate Social Responsibility Continuum as a Component of Stakeholder Theory", Business and Society Review, Vol. 110, No. 4, pp. 371-387.

13. Porter, E. M., Kramer, M. R. (2006), "The Link Between Competitive Advantage and Corporate Social Responsibility", Harvard Business Review, Vol. 84, No. 12, p. 78-92.

14. Ransburg, B., Vágási, M. (2011), "A fenntartható fejlődés vállalati integrációja és kommunikációja- a hazai nagyvállalati gyakorlat vizsgálata" (Corporate integration and communication of sustainable development - examination of the domestic enterprise practices), Vezetéstudomány-Budapest Management Review, Vol. 42, No. 10, pp. 2-13.

15. Rodek, N. (2018), "CSR EMAT- CSR Excellence Management and Assessment Tool", Thesis booklet of the PhD Dissertation, Doctoral School of Management Sciences and Business Administration. University of Pannonia, Veszprém.

16. Subáné, V. J. (2005), "A vállalat társadalmi felelősségtudata, mint a világmárka biztosítéka" (Corporate social responsibility as a guarantee of the world brand). Nemzetközi Marketing, No. 12.

17. Törőcsik, M. (2011), Fogyasztói magatartás- insigh, trendek, vásárlók (Consumer behavior- insight, trends, customers), Akadémiai Kiadó, Budapest.

18. Vogel, D. (2006), The Market for Virtue - The Potential and Limits of Corporate Social Responsibility, Brookings Institution Press, Washington, D. C.

19. Zoltayné, P. Z. (2002), "A tudásmenedzsment szerepe a döntéshozatalban" (The role of knowledge management in decision making), Vezetéstudomány-Budapest Management Review, Vol. 3, pp. 12-18.

\section{About the authors}

Nóra Rodek, PhD, is a senior lecturer at University of Pannonia Nagykanizsa Campus. She received her PhD in Management and Business Administration at the Doctoral School of University of Pannonia. Her research topics are CSR (Corporate Social Responsibility), sustainable and responsible management, social innovation. The author can be contacted at rodek.nora@uni-pen.hu.

Zsuzsanna Marton is an assistant research fellow at University of Pannonia Nagykanizsa Campus. Her university studies focused on Tourism (BA) and Marketing (MSC) which facilitated her to outline the preferred research fields such as tourism safety and security, destination image, marketing strategy and communication. The author can be contacted at marton.zsuzsanna@uni-pen.hu.

Ildikó Ernszt, PhD, is an associate professor at University of Pannonia Nagykanizsa Campus. She received her PhD degree in International Law at the University of Pécs, Faculty of Law. Her research topic is the safety and security of tourism. The author can be contacted at ernszt.ildiko@uni-pen.hu.

Zoltán Birkner, $\mathrm{PhD}$, is an associate professor at University of Pannonia Nagykanizsa Campus, a research specialist in the field of innovation performance of companies and regions and the manager of a water technology research and development center. The author can be contacted at birkner.zoltan@uni-pen.hu. 